\title{
MODEL KEBIJAKAN PEMERINTAH DESA DALAM PENGELOLAAN PASAR DESA DI KECAMATAN SUNGAI GELAM KABUPATEN MUARO JAMBI
}

\author{
Meri Yarni ${ }^{1}$, H. Irwandi, Hj. Netty \\ Fakultas Hukum Universitas Jambi, Indonesia \\ ${ }^{1}$ E-mail : meriyarni@yahoo.co.id
}

\begin{abstract}
Villages as the smallest entity of a regional government have an important role to play in the success of national development. Therefore the existence of the village remains inseparable from the central government regulation and is accommodated by its existence through Law No. 6 of 2014 concerning Villages. This study aims to find out and analyze the village government policy model in implementing the role of the Village Head in managing the village market in Sungai Gelam Sub-District, Muaro Jambi District and analyze the constraints faced by the Village Head in managing the village market. who are competent especially in carrying out the duties of the village head in the management of the village market, especially in the Sungai Gelam District of Muaro Jambi Regency. The research method used is a type of juridical empirical research with a legislative approach and a conceptual approach. From the results of the study it can be suggested that it should be to optimize the management of the village market in Sungai Gelam Sub-District, Muaro Jambi Regency, the village government is given the authority to issue a policy in village market management and the existence of standard management mechanisms and systems of correct accountability.
\end{abstract}

Keywords: Policy, Village Government, Village Market Management

\begin{abstract}
ABSTRAK
Desa sebagai entitas terkecil dari suatu pemerintahan daerah memiliki peran penting untuk mensukseskan pembangunan nasional. Oleh karena itu eksistensi desa tetap tidak dapat dilepaskan dari pengaturan pemerintah pusat dan diakomodir keberadaannya melalui UndangUndang Nomor 6 Tahun 2014 tentang Desa. Penelitian ini bertujuan mengetahui dan menganalisis model kebijakan pemerintah desa dalam pelaksanaan peranan Kepala Desa dalam pengelolaan pasar desa Kecamatan Sungai Gelam Kabupaten Muaro Jambi dan menganalisis kendala-kendala yang dihadapi oleh Kepala Desa dalam pengelolaan pasar desa Sedangkan kegunaan penelitian ini dapat sebagai acuan dan masukan bagi pihak yang berkompeten khususnya dalam pelaksanaan tugas dari kepala desa dalam pengelolaan pasar desa khususnya di Kecamatan Sungai Gelam Kabupaten Muaro Jambi. Metode penelitian yang digunakan adalah tipe penelitian yuridis empiris dengan pendekatan perundangperundangan dan pendekatan konseptual. Dari hasil penelitian dapat disarankan bahwa hendaknya untuk mengoptimalkan pengelolaan pasar desa di Kecamatan Sungai Gelam Kabupaten Muaro Jambi, pemerintah desa diberi kewenangan untuk mengeluarkan suatu kebijakan dalam pengelolaan pasar desa dan adanya mekanisme dan sistem pengelolaan yang baku serta system pertanggungjawaban yang benar.
\end{abstract}

Kata Kunci : Kebijakan, Pemerintah Desa, Pengelolaan Pasar Desa 


\section{Pendahuluan}

Pasal 18 ayat (1) Undang-Undang Dasar Negara Republik Indonesia, menyatakan: "Negara Kesatuan Republik Indonesia dibagi atas daerah-daerah propinsi, dan propinsi itu ibagi atas kabupaten dan kota, yang tiap-tiap propinsi, kabupaten dan kota itu mempunyai pemerintahan daerah yang diatur dengan undang-undang" Sebagai pelaksana pasal tersebut adalah Undang Undang Nomor 32 Tahun 2004 yang telah diubah dengan Undang-Undang Nomor 23 Tahun 2014 Tentang Pemerintahan Daerah. Selanjutnya mengenai pemerintahan desa di atur Undang-Undang Nomor 6 Tahun 2014 Tentang Desa, di dalam Pasal 19 UndangUndang Nomor 6 Tahun 2014 Tentang Desa Kewenangan Desa Meliputi : (a) Kewenangan berdasarkan hak asal usul; (b) Kewenangan local berskala Desa; (c) Kewenangan yang ditugaskan oleh Pemerintah, Pemerintah Daerah Provinsi, atau Pemerintah Daerah Kabupaten/Kota; dan (d) Kewenangan lain yang ditugaskan oleh Pemerintah, Pemerintah Daerah Provinsi, atau Pemerintah Daerah Kabupaten/Kota sesuai dengan ketentuan peraturan perundang-undangan. Kewenangan lokal bersekala Desa paling sedikit terdiri atas kewenangan: (a) Pengelolaan tambatan perahu; (b) Pengelolaan pasar Desa; (c) Pengelolaan tempat pemandian umum; (d) Pengelolaan jaringan irigasi; (e) Pengelolaan lingkungan pemukiman masyarakkat Desa; (f) Pembinaan kesehatan masyarakat dan pengelolaan pos pelayanan terpadu; (g) Pengembangan dan pembinaan sanggar seni dab belajar; (h) Pengelolaan perpustakaan Desa dan Taman bacaan; (i) Pengelolaan embung Desa; (j) Pengelolaan air minum bersekala Desa; (k) Pembuatan jalan Desa antar pemukiman ke wilayah pertanian.

Kewenangan memungkinkan Desa mempunyai kesempatan dan tanggung jawab mengatur rumah tangganya sendiri dan kepentingan masyarakat setempat, yang sekaligus akan menjadi bingkai bagi desa untuk membuat perencanaan lokal. Perencanaan Desa akan memberikan keleluasaan dan kesempatan bagi Desa untuk menggali inisiatif lokal (gagasan, kehendak dan kemauan lokal), yang kemudian dilembagakan menjadi kebijakan, program dan kegiatan dalam bidang pemerintahan dan pembangunan Desa. Berdasarkan latar belakang sebagaimana diuraikan di atas, permasalahan yang diteliti dapat diidentifikasi bentuk kebijakan pemerintah kecamatan dalam pembinaan dan pengawasan penyelenggaraan pemerintahan desa dan Kendala apa yang ditemukan oleh pemerintah kecamatan dalam pembinaan dan pengawasan penyelenggaraan pemerintahan desa 


\section{Analisis dan Pembahasan}

Pengelolaan merupakan terjemahan dari kata "management". Secara etimologi management yang diterjemahkan menjadi manajemen berasaldari kata "manus" yang berarti tangan dan kata "agree" yang berarti melakukan yang setelah digabung menjadi kata "manage" berarti mengurus atau "managiere" dari bahasa lating berarti melatih. Manajemen dapat diartikan merupakan suatu proses mengatur untuk mewujudkan tujuan yang di inginkan melalui fungsi-fungsinya antara lain planning, organising, actuating, dan controlling. ${ }^{1}$

Menurut Suharsimi, pengelolaan adalah berarti suatu tindakan yang dimulai dari penyususnan data, merencana, mengorganisasikan, melaksanakan, sampai dengan pengawasan dan penilaian. Pengelolaan akan menghasilkan sesuatu dan sesuatu itu dapat merupakan bentuk sumber penyempurnaan dan peningkatan pengelolaan terhadap rencana selanjutnya. $^{2}$

Undang-Undang Nomor 6 Tahun 2014 Tentang Desa yang menentukan: Dana Desa adalah dana yang bersumber dari Anggaran Pendapatan dan Belanja Negara yang diperuntukkan bagi Desa yang ditransfer melalui Anggaran Pendapatan dan Belanja Daerah Kabupaten/Kota dan digunakan

\footnotetext{
${ }^{1}$ Inu Kencana Syafiie, Manajemen Pemerintahan, Perca, Jakarta, 2008, hal. 1.

${ }^{2}$ Erni Tisnawati Sule, Kurniwan Saefullah, Pengantar Manajemen, Kencana Perdana Media Goup, Jakarta, 2009, hal. 6.
}

untuk membiayai penyelenggaraan pemerintahan, pelaksanaan pembangunan, pembinaan kemasyarakatan, dan pemberdayaan masyarakat". Dana desa adalah salah satu issu krusial dalam undangundang desa, penghitungan anggaran berdasarkan jumlah desa dengan mempertimbangkan jumlah penduduk, angka kemiskinan, luas wilayah, dan tingkat kesulitan geografis dalam rangka meningkatkan kesejahteraan dan pemerataan pembangunan desa. Karena issu yang begitu krusial, para senator menilai, penyelenggaraan pemerintahan desa membutuhkan pembinaan dan pengawasan, khususnya penyelenggaraan kegiatan desa.

Dana desa termasuk ke dalam lingkup Keuangan Desa sebagaimana yang ditentukan di dalam Pasal 71 UndangUndang Nomor 6 Tahun 2014 Tentang Desa. Pasal ini membatasinya dengan semua hak dan kewajiban yang menimbulkan pendapatan, belanja, pembiayaan, dan pengelolaan keuangan Desa. Berdasakan Pasal 72 Undang-Undang Nomor 6 Tahun 2014 Tentang Desa, ditentukan bahwa Pendapatan Desa bersumber dari:

a. pendapatan asli Desa terdiri atas hasil usaha, hasil aset, swadaya dan partisipasi, gotong royong, dan lainlain pendapatan asli Desa;

b. alokasi Anggaran Pendapatan dan Belanja Negara;

c. bagian dari hasil pajak daerah dan retribusi daerah Kabupaten/Kota; 
d. alokasi dana Desa yang merupakan bagian dari dana perimbangan yang diterima Kabupaten/Kota;

e. bantuan keuangan dari Anggaran Pendapatan dan Belanja Daerah Provinsi dan Anggaran Pendapatan dan Belanja Daerah Kabupaten/Kota;

f. hibah dan sumbangan yang tidak mengikat dari pihak ketiga; dan

g. lain-lain pendapatan Desa yang sah.

Hal ini sejalan dengan pendapat Nurcholis yang menyatakan bahwa: sumbersumber pendapatan desa berasal dari lima unsur berikut:

a. Pendapatan Asli Desa, antara lain terdiri dari hasil usaha desa, hasil kekayaan desa (seperti tanah kas desa, pasar desa, bangunan desa), hasil swadaya dan partisipasi, hasil gotong royong, dan lain-lain pendapatan asli desa yang sah;

b. Bagi hasil pajak daerah kabupaten/kota paling sedikit $10 \%$ (sepuluh persen) untuk desa dan dari retribusi kabupaten/kota yang sebagian diperuntukan bagi desa;

c. Bagian dari Dana Perimbangan Keuangan Pusat dan Daerah yang diterima kabupaten/kota untuk desa paling sedikit $10 \%$ (sepuluh persen), yang dibagi setiap desa secara proposional yang merupakan alokasi dana desa;

d. Bantuan keuangan dari pemerintah, pemerintah provinsi, dan pemerintah kabupaten/kota dalam rangka pelaksanaan urusan pemerintahan;

e. Hibah dan sumbangan dari pihak ketiga yang tidak mengikat. ${ }^{3}$

Aset sebagai salah satu unsur penting dalam rangka penyelenggaraan pemerintahan dan pelayanan masyarakat harus dikelola

\footnotetext{
${ }^{3}$ Hanif Nurcholis, Pertumbuhan dan Penyelenggaraan
} Pemerintahan Desa, Erlangga, Jakarta, 2011, hal. 82. dengan baik dan benar, yang pada gilirannya dapat mewujudkan pengelolaan aset dengan memperhatikan azas-azas seperti

dikemukakan oleh Dhani Nasution, bahwa:

1. Asas fungsional, yaitu pengambilan keputusan dan pemecahan masalah dibidang pengelolaan barang milik daerah yang dilaksanakan oleh kuasa pengguna barang, pengguna barang, pengelola barang dan Kepala Daerah sesuai fungsi, wewenang dan tanggungjawab masing-masing;

2. Asas kepastian hukum, yaitu pengelolaan barang milik daerah harus dilaksanakan berdasarkan hukum dan peraturan perundang-undangan;

3. Asas transparansi, yaitu penyeleggaraan pengelolaan barang milik daerah harus transparan terhadap hak masyarakat dalam memperoleh informasi yang benar.

4. Asas efisiensi, yaitu pengelolaan barang milik daerah diarahkan agar barang milik daerah digunakan sesuai batasanbatasan standar kebutuhan yang diperlukan dalam rangka menunjang penyelenggaraan tugas pokok dan fungsi pemerintahan secara optimal.

5. Asas akuntabilitas, yaitu pengelolaan barang milik daerah harus dapat dipertanggungjawabkan kepada rakyat.

6. Asas kepastian nilai, yaitu pengelolaan barang milik daerah harus didukung oleh adanya ketepatan jumlah dan nilai barang dalam rangka optimalisasi pemanfaatan dan pemindahtanganan baran milik daerah serta penyusunan neraca Pemerintah Daerah. ${ }^{4}$

Asas-asas pengelolaan aset diterapkan sebagai bentuk manajemen pemerintah yang mengacu pada prinsip-prinsip good

${ }^{4}$ Dhani Nasution, Pengaturan Penyerahan Aset Dari Daerah Induk Ke Daerah Pemekaran Dalam Penyelenggaraan Pemerintahan Daerah, , 2014, hal. 55-56. 
governance. Asas pemerintahan yang baik dapat dilihat dari 3 (tiga) aspek yaitu dari aspek teori, Aspek normatif dan aspek praktek $^{5}$. Secara teori dapat dikemukakan pendapat Kuntjoro Purbopranoto ${ }^{6}$, asas-asas umum tentang pemerintahan yang baik (The General Principle of Good Administration) itu dapat dikatagorikan ke dalam 13 (tiga belas) asas yaitu: Asas kepastian hukum (Principle of legal security); Asas keseimbangan (principle of proportionality); Asas Motivasi untuk setiap keputusan (Principle of motivation); Asas kesamaan dalam mengambil keputusan (pruinciple of quality); Asas bertindak cermat (principle of carefullness); Asas jangan campur adukan kewenangan (principle of non misuse of competence) Asas keadilan yang layak (principle of fair play); Asas keadilan dan kewajaran (principle of reasonableness or prohibition of cabitrariness); Asas menanggapi penghargaan yang wajar (principle of meeting raised expectation); Asas meniadakan akibat-akibat suatu keputusan yang batal (principle of doing the consequences of an annualleed decision); Asas perlindungan atau pandangan hidup/cara hidup pribadi (principle of protecting the personal way of life); Asas kebijaksanaan (principle of police); Asas

${ }^{5}$ Sukamto Satoto, Hukum Birokrasi dan Good Governance, Bahan Ajar Magister Ilmu Hukum Universitas Jambi, Jambi. 18 Maret 2007. ${ }^{6}$ Ibid. penyelenggaraan Kepentingan Umum

(principle of public service).

Penegakan hukum sebagai suatu proses, pada hakikatnya merupakan penerapan diskresi yang menyangkut membuat keputusan yang tidak secara ketat diatur oleh kaidah hukum, akan tetapi mempunyai unsur penilaian pribadi. $^{7}$ Menurut Lafavre yang menyatakan bahwa: "Pada hakikatnya diskresi berada diantara hukum dan moral (etika dalam arti sempit)". Atas dasar uraian tersebut dapatlah dikatakan bahwa gangguan terhadap penegakan hukum mungkin terjadi, apabila ada ketidakserasian antara "tritunggal" nilai, kaidah dan pola perilaku. Gangguan tersebut sering terjadi apabila terjadi ketidakserasian antara nilainilai yang berpasangan, yang menjelma di dalam kaidah-kaidah yang bersimpang siur, dan pola perilaku tidak terarah yang menggangu kedamaian pergaulan hidup. Dalam Penegakan hukum itu sendiri terdapat 5 (lima) faktor yang saling berkaitan, yaitu:

1. Faktor perundang-undangan, yang ditelusuri pada unsur bahasa perundangundangan dan perumusan sanksi;

2. Faktor aparat/penegak hukum berupa para aparat;

3. Faktor sarana dan fasilitas;

4. Faktor kesadaran hukum masyarakat, yaitu perihal ketaatan atau kepatuhan pada hukum;

5. Faktor kebudayaan. ${ }^{9}$

\footnotetext{
${ }^{7}$ Soerjono Soekanto, Faktor-Faktor Yang Mempengaruhi Penegakan hukum, Rajawali Pers, 2014, hal. 7.

${ }^{8}$ Ibid.

${ }^{9}$ Ibid., hal.12.
} 
Desa dengan hak otonomnya berhak mengelola keuangan desa secara mandiri. Baik, mengelola pendapatan dan sumbersumber pendapatan serta mengelola pembelanjaan anggaran tersebut. Akan tetapi, pada kenyataannya sangat banyak desa-desa yang belum dapat memanfaatkan keistimewaannya. Desa-desa tersebut sebagian besar hanya mengelola aset desa (pasar desa) untuk pendapatan desa kepada siapa yang mau mengerjakannya. Sesuai dengan apa yang dinyatakan dalam Pasal 26 Undang-Undang Nomor 6 Tahun 2014 ayat (1) dan (2) menyebutkan tentang tugas dan wewenang kepala desa, salah satunya yaitu : Memegang kekuasaan pengelolaan Keuangan dan Aset Desa. Hal ini dijelaskan lagi dalam Pasal 34 Peraturan Pemerintah Nomor 43 tahun 2014 tentang Peraturan Pelaksanaan Undang-Undang Nomoor 6 Tahun 2014 Tentang desa yang menyatakan bahwa Kewenangan local Desa berskala desa adalah dalam Pengelolaan pasar Desa. Desa Sungai Gelam sampai saat sekarang belum dapat mengoptimalkan sumber-sumber pendapatan desa dengan berbasis pada aset desa (pasar desa), karena pelaksanaannya masih dikelola oleh Pemerintah Daerah Kabupaten Muaro Jambi dalam hal ini Dinas Perindustrian dan Perdagangan. Sedangkan hasilnya tetap diberikan $40 \%$ ke desa. Desa mempunyai otonomi dan kewenangan dalam hal perencanaan, pelayanan publik, keuangan (APBDes), dan lain-lain. Mempunyai sistem demokrasi lokal. Artinya, dengan pemberian kewenangan pengelolaan pasar desa berdasarkan Peraturan Menteri Dalam Negeri Nomor 1 Tahun 2016 Tentang Pengelolaan Aset Desa dan Undang-Undang Nomor 6 Tahun 2014 tentang Desa, yang terjadi adalah desa diharapkan semakin maju dan makmur untuk kemudian semakin banyak keterlibatan aktif masyarakat mulai dari tahap perencanaan Musrenbang Desa pelaksanaan dan pengawasan pembangunan hingga pertangunggjawabannya. Namun, yang terjadi memang masih kembali lagi pada kapasitas aparat desa lagi dalam memahami perundangan, atau memang mereka paham akan tetapi peraturan demi kemudahan dan keuntungan aset desa semata.

Sumber Pendapatan Desa, Pendapatan asli desa, terdiri dari hasil usaha desa, hasil kekayaan desa, hasil swadaya dan partisipasi, hasil gotong royong, dan lain-lain. Pendapatan asli desa nantinya diharapkan dapat meningkatkan peran serta masyarakat, pelaksanaan otonomi desa yang diatur dalam undang-undang, diyakini akan mendorong desa untuk lebih bersikap mandiri karena memiliki kewenangan penuh untuk mengurus dan mengontrol desanya sendiri. Kemandirian tersebut, bisa menciptakan pertumbuhan ekonomi lebih balk, termasuk pengelolaan aset desa (pasar desa) yang lebih profesional dan bermanfaat mengena langsung kepada warga masyarakat. 
Kemandirian daerah ini memberikan aturan yang berlaku. Bertitik tolak dari hal kewenangan yang luas di satu sisi dan itu semenjak berlakunya Undang-Undang rnemaju kinerja aparat pemerintah desa untuk Nomor 6 Tahun 2014 Tentang Desa, bagi memberdayakan warga desanya. Dengan desa yang diberi hak menyelenggarakan adanya otonomi, maka otomatis desa akan rumah tangganya sendiri diharuskan setiap lebih kreatif dalam menggali penerimaan tahun Anggaran penerimaan dan pengeluaran pendapatan desanya.

Tidak semua desa yang ada di Kecamatan Sungai Gelam terdapat bentuk pemilikan demikian. Pengusahaan atas aset desa (pasar desa) tersebut diatur dengan musyawarah desa. Hal ini disebabkan pendapatan desa merupakan kekayaan dan sumber yang potensial untuk dikembangkan dalam suatu wilayah dengan memanfaatkan sumberdaya alam dan sumberdaya manusia setempat, serta mendatangkan pendapatan bagi masyarakat maupun pemerintah desa. Aset desa lainnya yang mandiri adalah merupakan desa yang memiliki daya saing, berorientasi sumberdaya manusia dan lingkungan, sehingga tercipta keunggulan kompetitif yang siap menghadapi persaingan global.

Dalam menyelenggarakan pemerintahan desa selama ini administrasi pemerintahan belum dikelola secara baik mulai dari perencanaan, pelaksanaan sampai kepada pengawasannya. Akibatnya sulit diketahui berapa jumlah sumber pendapatan dan keuangan desa yang telah ada serta pembangunan apa yang telah dilaksanakan. Kurang baiknya pengelolaan tersebut dikarenakan kurangnya pemahaman akan keuangan desa tersebut sama dengan Tahunan Anggaran Negara.

Penggunaan pasar desa yang menjadi sumber pendapatan desa adalah pada kolektif yang sekarang banyak dikelola oleh masyarakat yang berada pada wilayah desa itu sendiri. jenis-jenis aset desa di Desa Sungai Gelam Kecamatan Sungai Gelam Kabupaten Muaro Jambi, terdiri atas: (1) Pasar Desa; (2) Tanah Kas Desa dan (3) Bangunan desa.. Peranan kepala desa berperan dalam pengelolaan pasar desa sungai gelam tidak terlepas dari ketentuan Peraturan Menteri Dalam Negeri Nomor 1 Tahun 2016 Tentang Pengelolaan Aset Desa. Hal tersebut dapat dikemukakan sebagai berikut:

\section{a. Perencanaan;}

Proses perencanaan dalam hal ini melibatkan seluruh stack-holder yang ada didesa, dengan tujuan agar tujuan pembangunan tersentuh langsung oleh masyarakat dengan cara musyawarah desa terlebih dahulu. Tahap awal dalam proses perencanaan pengelolaan aset desa harus melalui musyawarah desa. Selanjutnya dilakukan pengalokasikan terlebih dahulu 
anggaran yang akan dipakai, setelah musyawarah desa selesai, pemerintah desa melakukan penyortiran dalam merencanakan perencanaan jangka pendek maupun jangka panjang. Perencanaan tersebut bersifat sederhana, yang berarti bahwa susunan rencana tersebut harus sistematis, prioritas jelas terlihat, semua kegiatan pokok yang akan dilaksanakan sudah tercakup. Dilaksanakan berdasarkan asas kepentingan umum, fungsional, kepastian hukum, keterbukaan, efisiensi, efektivitas, akuntabilitas, dan kepastian nilai ekonomi. Yang tertuang dalam Rencana Kerja Pemerintah Desa (RKPDes) yang Penyusunan RKPDes adalah untuk menyajikan dokumen perencanaan pembangunan tahunan desa yang sesuai dengan kebutuhan desa. Sesuai UU Desa setiap Desa wajib menyusun RKP Desa.

\section{b. Pengadaan;}

Pasal 9 Peraturan Menteri Dalam Negeri Nomor 1 Tahun 2016 Tentang Pengelolaan Aset Desa menentukan: (1) Pengadaan aset desa sebagaimana dimaksud dalam Pasal 7 huruf b, dilaksanakan berdasarkan prinsip-prinsip efisien, efektif, transparan dan terbuka, bersaing, adil/tidak diskriminatif dan akuntabel; (2) Pengadaan barang/jasa di desa diatur dengan Peraturan Bupati/Walikota dengan berpedoman pada ketentuan peraturan perundang-undangan. Bapak Isshahuddin (Sekretaris Desa), bahwa:
Aset desa yang dimiliki oleh Desa Sungai Gelam Kecamatan Sungai Gelam Kabupaten Muaro Jambi berupa pasar desa, tanah kas desa, pasar hewan dan bangunan desa. Pengelolaan aset desa ini tidak seluruhnya mendapat perhatian untuk ditindaklanjuti dengan pembuatan peraturan desa dan keputusan Kepala Desa salah satunya Pasar Desa. ${ }^{10}$ karena masih dikelola oleh pemerintah kabupaten.

\section{c. Penggunaan;}

Pasal 10 Peraturan Menteri Dalam Negeri Nomor 1 Tahun 2016 Tentang Pengelolaan Aset Desa menentukan: (1) Penggunaan aset Desa sebagaimana dimaksud dalam Pasal 7 huruf c, ditetapkan dalam rangka mendukung penyelenggaraan Pemerintahan Desa. (2) Status penggunaan aset Desa ditetapkan setiap tahun dengan Keputusan Kepala Desa.

Mengenai pendapatan dari pengelolaan pasar desa sudah ditentukan oleh pemerintah kabupaten untuk desa hanya diberi $40 \%$ sedangkan $60 \%$ untuk pemerintah kabupaten. Sebagaimana yang disampaikan oleh Bapak Isshahuddin (Sekretaris Desa Penggelolaan pasar desa di Desa Sungai Gelam Kecamatan Sungai Gelam Kabupaten Muaro Jambi ini sudah berlangsung sejak tahun 2008 sampai sekarang, tetapi hasil yang didapat untuk kas desa tidak jelas. Hasil yang diterima untuk

\footnotetext{
${ }^{10}$ Wawancara dengan Isshahuddin, Sekretaris Desa Sungai Gelam Tanggal 4 September 2018, di Kantor Desa Sungai Gelam Kecamatan Sungai Gelam Kabupaten Muaro Jambi.
} 
kas desa ini tidak mengalami penambahan lagi secara signifikan karena beberapa kali terjadi perbaikan pada sktruktur bangunan yang roboh dan rusak.

Pasar Desa dengan luas 2000M2 dan berdiri sejak Tahun 1991 dan terdiri dari kios-kios. Kemudian sejak tahun 2007 pasar desa sungai gelam sudah berubah menjadi 2 (dua) los dan 16 (enam belas) kios dan semakin berkembang dengan banyaknya lapak-lapak yang berubah-berubah jumlahnya setiap hari pasar. Berdasark apa yang dikatakan oleh Sekretaris Desa Sungai Gelam (Asis Shudin) pada tanggal 15 Oktober 2018 bahwa : Pasar desa yang terdiri dari Kios- kios disewakan Rp.4.000.000,- per tahun, sedangkan lapak disewakan Rp. 1500.000,- per tahun. Selama berdirinya pengelolaan pasar desa sampai sekarang dikelola oleh pemerintah kabupaten dalam hal ini Dinas Perindustrian dan Perdagangan Kabupaten Muaro Jambi. Artinya sewa pengelolaan keuangan pasar masuk ke Pemerintah Daerah Kabupaten. Hanya saja dalam realisasinya $40 \%$ diberikan ke Desa. Mualai Tahun 2018 diberlakukan retribusi dengan rincian Rp. 2000/pedagang yang dikelola oleh desa dan dijadikan pendapatan asli desa (PAD), tetapi dasar penarikan tersebut belum dapat secara formal dikeluarkan oleh Pemerintah Desa tidak ada kewenangan yang diberikan oleh pemerintah kabupaten.
Selanjutnya Bapak Isshahuddin juga mengatakan bahwa mengenai kewajiban pedagang adalah membayar retribusi setiap hari pekan/kalangan dengan rincian sewa petak sebesar Rp. 300.000,/M²/Bulan, untuk los Rp. 150.000,-/bulan dan retribusi kebersihan sebesar Rp. 5.000. Setiap pedagang tidak semuanya selalu membayar kewajibannya tepat pada waktunya tergantung dari pendapatan yang mereka terima. Apabila hasil penjualannya mengalami penurunan maka pembayaranpun belum dibayarkan tepat pada waktunya. Penagihan retribusi biasanya dilakukan oleh petugas pengelola pasar setiap bulannya paling lambat 20 bulan berjalan. Bila terlambat dari waktu yang telah ditentukan dikenakan denda $10 \%$ (sepuluh persen) setiap satu bulan dari jumlah yang terhutang.

\section{Kendala-Kendala Yang Dihadapi Oleh Kepala Desa Dalam Pengelolaan Pasar Desa}

Pengelolaan pasar desa di Kabupaten Muaro Jambi khususnya di Kecamatan Sungai Gelam sesuai dengan petunjuk yang mengacu pada Peraturan Menteri Dalam Negeri Nomor 1 Tahun 2016 Tentang Pengelolaan Aset Desa. Berbeda halnya dengan pengelolaan hasil Pasar Desa Sungai Gelam sistemnya cukup baik, paling tidak sampai mencapai target atau rencana yang diharapkan karena pedoman yang tidak ada dan tidak jelas. Hal ini juga disebabkan 
karena mulai dari pelaporan, penyimpanan dan penggunaan serta target yang ingin dicapai terpola secara sistematis, sehingga dapat mencegah Kepala Desa dalam penggunaan secara tidak berdayaguna, meskipun disinyalir masih ada Kepala Desa tidak melaporkan hasil Pasar Desa Sungai Gelam secara jujur.

Kemudian dimungkinkan Kades yang memiliki pasar desa untuk dapat menyampaikan laporan perkembangan pasar desa dengan ketentuan sebagai berikut:

1. Pengelolaan dan perkembangan Pasar Desa dilaporkan oleh Kades/Lurah kepada Camat secara berkala setiap triwulan

2. Camat merekap laporan Pasar Desa perdesaan/kelurahan untuk selanjutnya dilaporkan kepada Bupati setiap triwulan atau 5 Bulan berikutnya.

3. Bentuk laporan pengelolaan dan perkembangan Pasar Desa harus mengacu pada Peraturan Menteri Dalam Negeri Nomor 1 Tahun 2016 Tentang Pengelolaan Aset Desa.

Implementasi pengelolaan Pasar Desa untuk meningkatkan pendapatan desa di Kabupaten Sungai Gelam, menurut Kepala Desa Sungai Gelam tidak berjalan sebagaimana mestinya, dikarenakan adanya beberapa hal, diantaranya banyak pedagang yang menunggak pembayaran sewa pasar desa. Berbagai permasalahan yang melingkupi pengelolaan pasar desa sebenarnya sangat "disayangkan", karena mengingat arti penting tentang aset desa tersebut. Menurut Kepala Desa Sungai Gelam yaitu:

Pengelolaan pasar desa menjadi begitu penting dan mendasar dalam pelaksanaan otonomi desa, sebab saat ini terbuka lebar kesempatan bagi desa untuk mengelola pasar desa, agar mendapat hasil yang optimal. Modal inilah yang kemudian harus secara cerdas dan kreatif dapat dikelola oleh desa agar kemampuan dalam pembiayaan penyelenggaraan pemerintahan desa, pembangunan dan kesejahteraan masyarakat dapat diwujudkan

Aturan yang mengatur pasar desa tersebut bisa diperjelas dengan mengkaji ulang aturan yang ada. Menurutnya, keberhasilan optimalisasi pengelolaan pasar desa tidak lepas dari dukungan dan partisipasi semua komponen (stakeholders) baik Pemerintahan Desa, Pemerintah Kabupaten, Pemerintah Provinsi, swasta dan masyarakat, serta adanya faktor-faktor pendukung berupa fasilitasi kegiatan inventarisasi pasar desa, pembinaan melalui penyuluhan kepada Kepala Desa dan Perangkat desa.

$$
\text { Optimalisasi pengelolaan juga }
$$
dipengaruhi oleh faktor bagaimana Pemerintah Desa mampu untuk mengevaluasi hasil kerja dalam pengelolaan pasar desanya selama ini, sekaligus membuat rencana kegiatan yang baru dalam pengelolaan pasar desanya, dan yang tidak 
kalah penting adalah faktor adanya kesempatan untuk melakukan pengelolaan yang berupa tawaran dari investor atau pihak ketiga, dan kepemilikan sumber daya lain terutama sumber daya alam.

Kemudian menurut salah seorang anggota BPD Desa Sungai Gelam Kecamatan Sungai Gelam Kabuapten Muaro Jambi yang menerangkan bahwa kendalakendala yang tergolong sebagai kendala internal (dalam lembaga pemerintah desa itu sendiri) dalam kata lain kepala desa dan perangkat desa itu. Selanjutnya kendala eksternal yang lain adalah kurangnya Sumber Daya Manusia (SDM) yang memadai yakni di kantor Desa Sungai Gelam Kabupaten Muaro Jambi kekurangan staf ahli yang khusus mengurusi pengelolaan aset desa, dan yang menjadi permasalahan selanjutnya adalah staf desa yang mengurusi aset desa sekarang kurang mengatahui bagaimana pengelolaan aset desa yang baik dan benar sehingga berpengaruh pada proses pemanfaatan aset dan kesejahteraan di Desa Sungai Gelam Kabupaten Muaro Jambi . Selanjutnya yang menjadi kendala eksternal adalah kurangnya kesadaran dari masyarakat desanya sendiri terhadap budaya gotongroyong dan rasa tanggung jawabnya akan kesadaran bersama memelihara aset -aset desa yang bersifat bergerak dan tidak bergerak.

\section{Kesimpulan dan Saran}

Peranan Kepala Desa dalam mengeluarkan suatu kebijakan dalam pengurusan pasar desa belum dilakukan secara baik dan benar, hal ini terbukti kepala desa belum bisa mengeluarkan suatu bentuk kebijakan karena memiliki kewenangan, sehingga tidak memberikan keuntungan dan pemasukan ke kas desa. Hal ini dipandang tidak produktif akibat pola pengelolaan yang kurang jelas . akhirnya pasar desa belum memberi manfaat terhadap peningkatan pendapatan desa.

Kendala-kendala yang tergolong sebagai kendala internal berupa: Tingkat pendidikan aparat pemerintah desa dan sebagian besar anggota BPD yang masih kebanyakan lulusan SLTP dan pengetahuan dan pemahaman hukum yang masih dikatakan awam dimiliki oleh aparat pemerintah desa. Sedangkan kendala eksternal yaitu: pemahaman yang keliru dikalangan masyarakat tentang (Anggaran Pendapatan dan Belanja Desa dan Anggaran Dana Desa.

Adapun saran yang dapat diberikan yakni : pengelolaan pasar desa hendaknya disempurnakan dan adanya mekanisme dan sistem pengelolaan yang baku serta pertanggungjawaban kepada pihak-pihak yang memenuhi dan melakukan penyimpangan dalam pengelolaan pasar desa, sehingga hal ini akan menjadi penekanan 
pihak pemerintah desa dan khususnya Badan Permusyawaratan Desa Sungai Gelam meningkatkan kinerjanya dalam melakukan pengawasan terhadap kinerja pemerintah desa khususnya dalam melakukan pengelolaan pasar desa.

\section{Referensi}

Bayu Surianingrat. (1981). Wewenang, tugas dan tanggungjawab Camat, Cetakan ke dua.Jakarta: penerbit Patco.

BN Marbun. (20005). DPRD Pertumbuhan dan Cara Kerjanya, Pustaka Sinar Harapan, Jakarta, 2005

Jimly Asshadiq, Pokok-pokok Hukum Tata Negara Indonesia, PT. Buana Ilmu Populer, Jakarta

J.Kaloh. (2007). Mencari Bentuk Otonomi Daerah, Jakarta:Rineka Cipta.

Indroharto. (2005). Perbuatan Pemerintah Menurut Hukum Publik dan Hukum Perdata.Bogor:Lembaga Penelitian dan Pengembangan Hukum Administrasi Negara.

Juanda. (2008). Hukum Pemerintahan Daerah Pasang Surut Hubungan Kewenangan antara DPRD dan Kepala Daerah.Bandung:Alumni.

Kusnardi dan Hermalili Ibrahim. (1988). Pengantar Hukum Tata Negara. Jakarta: Sinar Sakti.

Rozali Abdullah. (2011). Pelaksanaan Otonomi Luas, Raja wali Pers, Jakarta.

Solly Lubis. (1983). Perkembangan Garis Politik dan Perundang-undangan Pemerintahan Daerah. Bandung: Alumni.

\section{B.Peraturan Perundang-undangan}

Republik Indonesia, Undang-Undang Dasar Negara Republik Indonesia Tahun 1945

, Undang-Undang Nomor 32 Tahun 2004 Tentang Pemerintah Daerah (Lembaran Negara Republik Indonesia Tahun 2004 Nomor 125, Tambahan Lembaran Negara Republik Indonesia Nomor 4437.

-. Undang-Undang Nomor 6 Tahun 2014 tentang Desa

, Peraturan Pemerintah Nomor 19 Tahun 2008 Tentang Kecamatan (Lembaran Negara Republik Indonesia Tahun 2008 Nomor 40). 